\title{
Unveiling Pharmacological Responses and Potential Targets Insights of Identified Bioactive Constituents of Cuscuta reflexa Roxb. Leaves through In Vivo and In Silico Approaches
}

\author{
Md. Adnan ${ }^{1,+}+{ }^{\circ}$, Md. Nazim Uddin Chy ${ }^{2,3,+} \oplus$, A.T.M. Mostafa Kamal ${ }^{2, *}$, \\ Md. Riad Chowdhury ${ }^{2}$, Md. Shariful Islam ${ }^{2}$, Md. Amzad Hossain ${ }^{2}$, Abu Montakim Tareq ${ }^{2}$ (D), \\ Md. Imam Hossain Bhuiyan ${ }^{2}$, Md Nasim Uddin ${ }^{2}$, Afroza Tahamina ${ }^{4}$, \\ Md Obyedul Kalam Azad ${ }^{1}\left(\mathbb{D}\right.$, Young Seok Lim ${ }^{1, *}$ and Dong Ha Cho ${ }^{1, *}$ \\ 1 Department of Bio-Health Technology, Kangwon National University, Chuncheon 24341, Korea; \\ mdadnan1991.pharma@gmail.com (M.A.); azadokalam@gmail.com (M.O.K.A.) \\ 2 Department of Pharmacy, International Islamic University Chittagong, Chittagong 4318, Bangladesh; \\ nazim107282@gmail.com (M.N.U.C.); riadchy01@gmail.com (M.R.C.); \\ shariful.islam02@northsouth.edu (M.S.I.); ctg.amzad.edu@gmail.com (M.A.H.); \\ montakim0.abu@gmail.com (A.M.T.); imamhossain037@gmail.com (M.I.H.B.); \\ mdnasimuddin2018@gmail.com (M.N.U.) \\ 3 Drug Discovery, GUSTO A Research Group, Chittagong 4000, Bangladesh \\ 4 Beijing Advanced Innovation Center for Food Nutrition and Human Health, Beijing Technology \\ and Business University, Beijing 100048, China; tahaminasompurna@gmail.com \\ * Correspondence: mostafa@pharm.iiuc.ac.bd (A.T.M.M.K.); potatoschool@kangwon.ac.kr (Y.S.L.); \\ chodh@kangwon.ac.kr (D.H.C.) \\ + These authors contributed equally to this work.
}

Received: 26 February 2020; Accepted: 19 March 2020; Published: 20 March 2020

\begin{abstract}
Cuscuta reflexa Roxb. is traditionally used by the indigenous communities of Bangladesh to treat different diseases, such as pain, edema, tumor, jaundice, and skin infections. This study tested neuro-pharmacological, anti-nociceptive, and antidiarrheal activities by in vivo and in silico experiments for the metabolites extracted (methanol) from the leaves of Cuscuta reflexa (MECR). During the anxiolytic evaluation analyzed by elevated plus maze and hole board tests, MECR (200 and $400 \mathrm{mg} / \mathrm{kg}$ ) exhibited a significant dose-dependent reduction of anxiety-like behavior in mice. Similarly, mice treated with MECR demonstrated a dose-dependent decrease in the time of immobility in both forced swimming and tail suspension tests. In addition, anti-nociceptive activity was assessed by the chemical-induced (acetic acid and formalin) pain models. In both cases, $400 \mathrm{mg} / \mathrm{kg}$ was found to be most effective and significantly $(p<0.001)$ inhibited acetic acid stimulated writhing and formalin-induced licking (pain response) in mice. Furthermore, antidiarrheal efficacy determined by the castor-oil induced diarrheal model manifested an evident inhibition of diarrheal stool frequency. In parallel, previously isolated bioactive compounds were documented based on the biological activities and subjected to in silico studies to correlate with the current pharmacological outcomes. The selected isolated compounds (15) displayed favorable binding affinities to potassium channels, human serotonin receptor, COX-1, COX-2, M3 muscarinic acetylcholine receptor, and 5-HT3 receptor proteins. Additionally, the ADME/T and toxicological properties were justified to unveil their drug-like properties and toxicity level. Overall, Cuscuta reflexa is bioactive and could be a potential source for the development of alternative medicine.
\end{abstract}

Keywords: Cuscuta reflexa; anxiolytic; antidepressant; anti-nociceptive; antidiarrheal; molecular docking; ADME/T; admetSAR 


\section{Introduction}

Traditional medicine is the most available and affordable source of treatment for many diseases [1]. Since primitive times, several activities of medicinal plants have been discovered in practices of traditional medicine [2]. These activities are the consequence of various bioactive compounds that provide adequate defensive advantages to the plant [3]. Different plants possess different phytochemicals, leading to diversity in the activity of each plant. These phytochemicals can be isolated and used in the development of novel drugs. However, most of the diseases are currently being treated by using synthetic medicines, even though they hold numerous side effects [4]. Two such diseases are anxiety and depression, in which $3.8 \%$ and $3.4 \%$ of the global population respectively are suffering from [5]. Although some chemical drugs are available for treatment purposes, due to their side effects, many patients prefer herbal medicine [6].

Similarly, most of the analgesic drugs such as COX-2 inhibitors and opioids exhibit some unwanted adverse effects, including liver failure, GIT disorder, kidney dysfunction, and neutropenia [7,8]. Thus, medicinal plants can be an essential source for the development of analgesic drugs as they have wide traditional popularity [9]. Furthermore, diarrhea is another condition which is found to be the second leading cause of death of children and infant [10]. Due to the widespread application of herbal medicine, the WHO has encouraged to use medicinal plants for the treatment of diarrhea [11]. Also, because of its fewer complications, medicinal plants have been implemented as alternative therapy in different countries for thousands of years [12].

Cuscuta reflexa Roxb. is such a medicinal herb belonging to the family Convolvulaceae, commonly known as Dodder (English), Swarnalata (Bengali), Akashabela or Amarabela (Hindi) and Akakhilata (Assamese) [13]. It is found in tropical and temperate regions such as India, Malaysia, Thailand, Nepal, and Afghanistan [13,14]. The tribes of Bangladesh and Nepal use this herb to treat pain, edema, and tumor, to maintain the hepatic system, to cure jaundice and skin infections $[15,16]$. It is also traditionally used for the treatment of insanity, melancholy, diaphoretic, demulcent, fits, and fever [14,17]. Previous research suggests that C. reflexa has been found to possess several activities, including antioxidant, antibacterial, antispasmodic, hypoglycemic, hemodynamic, antihypertensive, antiviral, and anticonvulsant [18-21]. Additionally, a wide range of bioactive constituents has been isolated from this herb, including kaempferol, astragalin, myricetin, quercetin, isorhamnetol, linoleic acid, oleic acid, stearic acid, palmitic acid, $\beta$-sitosterol, luteolin, coumarin, $n$-hentriacontane, $\alpha$-amyrin, and sesamin [18]. Although C. reflexa holds extensive traditional uses, some of the pharmacological activities of this herb are yet to be investigated. Therefore, the present study is aimed to explore in vivo neuro-pharmacological, anti-nociceptive, and antidiarrheal activities of methanolic extract of Cuscuta reflexa. Furthermore, the isolated bioactive compounds from this herb were evaluated for the selected activities through in silico approaches, namely molecular docking and pharmacokinetic properties, including absorption, distribution, metabolism, excretion, and toxicity (ADME/T).

\section{Materials and Methods}

\subsection{Identification and Preparation of Plant Extract}

The Cuscuta reflexa Roxb. leaves were collected from Noakhali, and the plant was authenticated by Dr. Shaikh Bokhtear Uddin, Taxonomist and Professor, Department of Botany, University of Chittagong with a reference number (SUB 3219) which has been deposited at the Department of Pharmacy, International Islamic University, Chittagong, Bangladesh and also in the Herbarium of the University of Chittagong for future reference. To prepare the crude extract, the grinded powder $(250 \mathrm{~g})$ was soaked in sufficient methanol $(700 \mathrm{~mL})$ for 7 days and vigorously shaken. Then, the entire mixture solutions were filtered and evaporated by using the rotary evaporator to obtain the sticky semi-solid mass which was reserved in $4{ }^{\circ} \mathrm{C}$. 


\subsection{Chemicals}

Methanol, acetic acid, and formalin were obtained from Merck (Darmstadt, Germany). Diazepam, imipramine hydrochloride, Loperamide and diclofenac sodium were obtained from Square Pharmaceuticals Ltd. All other chemicals used in this research were of analytical reagent grade until unless specified with additional reference.

\subsection{Experimental Animals and Ethical Statements}

Adult Swiss Albino mice weighing 25-30 g of both male and female were obtained from Jahangir Nagar University, Savar, Bangladesh. All experimental protocols (Pharm-P\&D-61/08'19-127) were approved by the institutional animal ethics committee of Department of Pharmacy, International Islamic University Chittagong, Bangladesh.

\subsection{Acute Oral Toxicity Test}

The acute oral toxicity test was performed using standard laboratory conditions according to the "Organization for Environmental Control Development" guidelines (OECD: Guidelines 420; Fixed Dose Method).

\subsection{Experimental Design (Drugs and Treatments)}

Experimental animals (24 mice for each experiments) were separated into four groups (control, standard, and test groups) containing six mice in each section. The test groups were administrated MECR at doses of 200 and $400 \mathrm{mg} / \mathrm{kg}$, b.w, p.o, respectively, whereas the control group received vehicle ( $1 \%$ Tween 80 in water, $10 \mathrm{~mL} / \mathrm{kg}$, p.o). The standard drug diazepam $(1 \mathrm{mg} / \mathrm{kg}$, b.w, i.p) was used in elevated plus maze test and hole-board test, while imipramine hydrochloride $(10 \mathrm{mg} / \mathrm{kg}, \mathrm{b} . \mathrm{w}$, i.p) was used for tail suspension test (TST) and forced swim test (FST). The diclofenac sodium $(10 \mathrm{mg} / \mathrm{kg}$ b.w, p.o) was administrated to the mice for an acetic acid induced writhing and formalin induced hind paw licking test. In addition, loperamide $(5 \mathrm{mg} / \mathrm{kg})$ was used for the castor-oil induced anti-diarrheal test. Importantly, the reference drugs (diazepam, imipramine hydrochloride, diclofenac sodium, and loperamide) were administrated at $15 \mathrm{~min}$ and MECR (200 and $400 \mathrm{mg} / \mathrm{kg}$ ) or vehicle at $30 \mathrm{~min}$ prior to the experiments.

\subsection{Anxiolytic Activity}

\subsubsection{Elevated Plus Maze Test (EPM)}

The elevated plus maze (EPM) test was performed to investigate the anxiolytic activity of MECR in mice [22]. The apparatus (situated above $40 \mathrm{~cm}$ of the floor) used in this test contained two open arms $(5 \times 10 \mathrm{~cm})$ and two closed arms $(5 \times 10 \times 15 \mathrm{~cm})$ which together merged in a center platform $(5 \times 5 \mathrm{~cm})$ and exposed as symbol of plus sign. The randomly distributed animals $(n=6)$ of each group were administrated as mentioned in Section 2.5. After thirty minutes, each treated animal was kept in the midpoint of platform, facing to the closed arms and allowed for free roaming for $5 \mathrm{~min}$. During exploration, open arms entrance and total time spent were recorded.

$$
\% \text { of entries in the open arm }=\frac{\text { No. of entries in the open arm }}{\text { No. of entries in the open arm }+ \text { No. of entries in the closed arm }} \times 100
$$

\subsubsection{Hole-Board Test for Exploratory Behaviour in Mice (HBT)}

In this test, a grid-pattern likes sixteen holes (diameter $3 \mathrm{~cm}$ ) contained flat platform with enclosed space $(40 \times 40 \times 25 \mathrm{~cm})$ was used as an experimental apparatus which was set up $25 \mathrm{~cm}$ above the floor [23]. Dosing treatments for each group of animal are described in Section 2.5. Thirty minutes after post administration of test dose, the experimental animal was situated on the middle of the board 
and allowed to free movement. Finally, head dipping number through the holes by mice were counted for $5 \mathrm{~min}$.

\subsection{Antidepressant Activity}

\subsubsection{Forced Swim Test (FST)}

The force swimming test was carried out to evaluate the antidepressant activity of MECR in mice as previously described method [24]. This experiment was performed in two sessions, for instance, preliminary test was conducted the day before the final experiment in order to adapt the animals with environment. A transparent glass tank $(25 \times 15 \times 25 \mathrm{~cm})$ filled up to $15 \mathrm{~cm}$ with water $\left(25 \pm 1{ }^{\circ} \mathrm{C}\right)$ was used as an experimental apparatus for swimming. Mice of all groups were treated (tests dose, standard drug and vehicle) as mentioned in Section 2.5. After thirty munities, each mouse was placed in the tank for $6 \mathrm{~min}$ where first $2 \mathrm{~min}$ was considered as initial adjustment time and the next $4 \mathrm{~min}$ was recorded as the immobility duration.

\subsubsection{Tail Suspension Test (TST)}

The tail suspension test is simple and most reliable method to screen the antidepressant activity of MECR [25]. After the administration of all doses, as described in Section 2.5, mice were induced into a state of depression (immobility), hanging by the end of tail using adhesive tape (nearly $1 \mathrm{~cm}$ from the tip of the tail). The total time of immobility was recorded during the last four minute of a total six minute for each mouse of all groups.

\subsection{Anti-Nociceptive Activity}

\subsubsection{Acetic Acid-Induced Writhing Test}

This test has been conducted to evaluate the anti-nociceptive activity of MECR in mice, followed by the method of Adnan et al. [26]. The randomly divided experimental mice $(n=6)$ of each group were treated as described in Section 2.5 above. After 30 min of treatment, acetic acid $0.6 \%(\mathrm{v} / \mathrm{v})$ was intraperitoneally injected in mice to induce writhing (abdominal pain). Five min after administration of acetic acid, the writhing number for each mouse was counted for $20 \mathrm{~min}$. The percentage of inhibition was measured by using following equation:

$$
\text { Inhibition }(\%) \text { of writhing }=\frac{\text { Total number of writhing }(\text { control }- \text { test group })}{\text { Total writhing number of the control }} \times 100
$$

\subsubsection{Formalin Induced Licking Test}

In this test, the allocated experimental mice of various groups were administrated as described in Section 2.5. Thirty minutes later of all treatment, a formalin solution $(2.5 \%, \mathrm{v} / \mathrm{v}, 20 \mu \mathrm{L})$ was injected in sub-plantar region of hind paw of mice to induce pain. Mice reflected pain response by licking and biting the hind paw (the injected area) which was counted during both the first phases ( $5 \mathrm{~min}$ ) and the late phase (15-30 $\mathrm{min})$. The percentage of inhibition of licking time was calculated as described in [26].

\subsection{Anti-Diarrheal Activity}

\section{Castor Oil-Induced Diarrhea}

The antidiarrheal activity of MECR was performed according to the method described previously [27]. The allocated mice were fasted for $24 \mathrm{~h}$ and dosing treatments for each group of mice $(n=6)$ were described in Section 2.5. Mice were orally treated with castor oil $(0.5 \mathrm{~mL})$ and individually placed in the blotting paper cage after $1 \mathrm{~h}$ of administration. Each $1 \mathrm{~h}$ after, blotting 
paper was changed and the numbers of both dry and wet faeces excreted by the mice were counted during the 4-h observation period. The percent of inhibition of defecation and diarrhea are counted by using following equation:

$$
\text { Inhibition }(\%) \text { of Diarrhea }=\frac{\text { Total number of diarrheal faces (control-test group) }}{\text { Total number of diarrheal faces of the control }} \times 100
$$

\section{In Silico Studies}

\subsection{Molecular Docking Analysis: Ligand Preparation}

The chemical structures of fifteen major compounds of MECR were downloaded from PubChem compound repository (https://pubchem.ncbi.nlm.nih.gov/). The ligand was prepared by using the LigPrep tool, which embedded in Schrödinger suite-Maestro v 10.1, where the following parameters were used as follows: neutralized at pH 7.0 2 2.0 using Epik 2.2 and the OPLS_2005 force field were used for minimization.

\subsubsection{Molecular Docking Analysis: Enzyme/Receptor Preparation}

Three-dimensional crystallographic structures of enzyme/receptors were obtained from the Protein Data Bank RCSB PDB [28] potassium channel receptor (PDB: 4UUJ) [29], human serotonin receptor (PDB: 5I6X) [30], cyclooxygenase-1 (COX-1, PDB: 2OYE) [31], cyclooxygenase-2 (COX-2, PDB: 3HS5) [32], M3 muscarinic acetylcholine receptor (PDB: 4U14) [33], and 5-HT3 receptor (PDB: 5AIN) [34]. The enzyme/receptor was prepared for a docking experiment using Protein Preparation Wizard, which embedded in Schrödinger suite-Maestro v 10.1.

\subsubsection{Molecular Docking Analysis: Glide Standard Precision Docking}

A molecular docking study was performed to reveal the possible mechanism of action of the selected compounds behind the biological activities of the MECR against the respective enzymes/receptor for an anxiolytic, antidepressant, anti-nociceptive, and antidiarrheal activity. Docking experiments were performed using Glide standard precision docking, which was embedded in Schrödinger suite-Maestro v 10.1, as we described previously [27].

\subsection{In Silico Study: Determination of Pharmacokinetic Parameters by SwissADME}

The pharmacokinetic parameters or drug-likeness properties of the selected compounds were determined by SwissADME online tool (http://www.swissadme.ch/). In the present study, an orally active drug should fulfill the following drug-likeness parameters to demonstrate their pharmaceutical fidelity such as molecular weight of the compounds, Lipophilicity (LogP), the number of hydrogen-bond acceptors, and the number of hydrogen-bond donors based on the Lipinski's rule.

\subsection{In Silico Study: Toxicological Properties Prediction by admetSAR}

Toxicological properties of the selected compounds were determined using the admetSAR online tool (http://lmmd.ecust.edu.cn/admetsar1/predict/) sine toxicity is a prime concern during the development of new drugs. In the present study, Ames toxicity, carcinogenic properties, acute oral toxicity, and rat acute toxicity were predicted.

\section{Statistical Analysis}

The data were expressed as mean \pm standard error of mean (SEM). Statistical comparisons were performed using one-way ANOVA followed by Dunnett's multiple comparison tests. The values obtained were compared with the vehicle control group and were considered statistically significant when $p<0.05$. 


\section{Result}

\subsection{Elevated Plus Maze (EPM)}

Figure 1 illustrated the potential effect of MECR in EPM test. Administration of MECR (400 and $200 \mathrm{mg} / \mathrm{kg}$ ) demonstrated a dose depend increase of locomotion (spending time in the open arms). Particularly, $400 \mathrm{mg} / \mathrm{kg}$ significantly $(p<0.01)$ elevated the percentage of time spent in the open arms $(41.66 \pm 0.56)$, whereas $200 \mathrm{mg} / \mathrm{kg}$ responded a moderate $(36.86 \pm 2.62)$ but significant $(p<0.05)$ anxiolytic influence compared to the control group. In contrast, diazepam (reference standard drug, at $1 \mathrm{mg} / \mathrm{kg}$, i.p.) treated mice exposed a marked acceleration $(p<0.001)$ in the percentage of open arms time spent $(69.46 \pm 1.70)$.

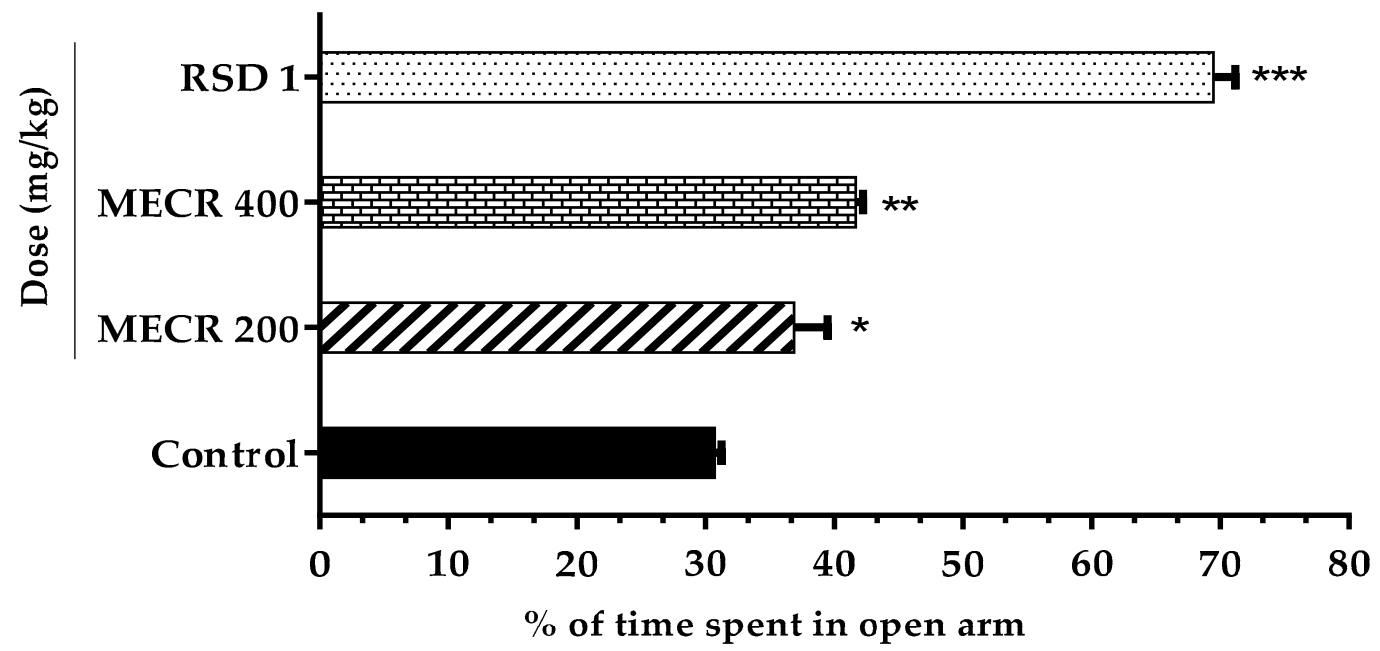

Figure 1. The effect of methanol extract of Cuscuta reflexa (MECR) in EPM test in mice. Values are expressed in mean \pm SEM $(\mathrm{n}=6) .{ }^{*} p<0.05,{ }^{* *} p<0.01$ and ${ }^{* * *} p<0.001$ compared with the control group (Dunnett's test). RSD: reference standard drug (Diazepam, $1 \mathrm{mg} / \mathrm{kg}$ ).

Hole Board Test (HBT)

In this test, mice treated with MECR (200 and $400 \mathrm{mg} / \mathrm{kg}$ ) exhibited notable exploratory behavior in a dose-dependent fashion (Figure 2). Particularly, the treatment of $400 \mathrm{mg} / \mathrm{kg}$ revealed a significant $(p<0.001)$ hole poking tendency followed by a higher number of head dipping $(41.40 \pm 2.42)$ compared to $200 \mathrm{mg} / \mathrm{kg}(34.40 \pm 1.63) ;(p<0.05)$. In addition, the positive control diazepam ( $1 \mathrm{mg} / \mathrm{kg}$, i.p.) revealed $(p<0.001)$ higher number of head dipping $(64.33 \pm 2.32)$ in comparison to the control group $(26.33 \pm 1.44)$.

\subsection{Forced Swimming Test (FST)}

The antidepressant efficiency of MECR (200 and $400 \mathrm{mg} / \mathrm{kg}$ ) studied by force swimming test was displayed in Figure 3. Over the observation period during FST test, the depressive behavior, such as time of immobility ( $\mathrm{sec}$ ) was decreased in a significant dose-dependent manner. Mice administrated with $400 \mathrm{mg} / \mathrm{kg}$ apparently manifested worth mentioning $(p<0.001)$ immobile time $(95.6 \pm 3.14 \mathrm{~s})$ which was analogous $(p<0.001)$ to the immobile time $(88.3 \pm 2.07 \mathrm{~s})$ of imipramine $(10 \mathrm{mg} / \mathrm{kg})$, used as a reference (standard) antidepressant. In contrast, $200 \mathrm{mg} / \mathrm{kg}$ also showed a slight decrease in time of immobility $(178 \pm 8.60 \mathrm{~s})(p<0.05)$ as compared to control group $(194.4 \pm 4.57 \mathrm{~s})$. In addition, the percentage of decrease in immobility (depression) for imipramine, MECR 200, and 400mg/kg was estimated $54.57,8.43 \mathrm{~s}$, and $50.82 \%$ respectively. 


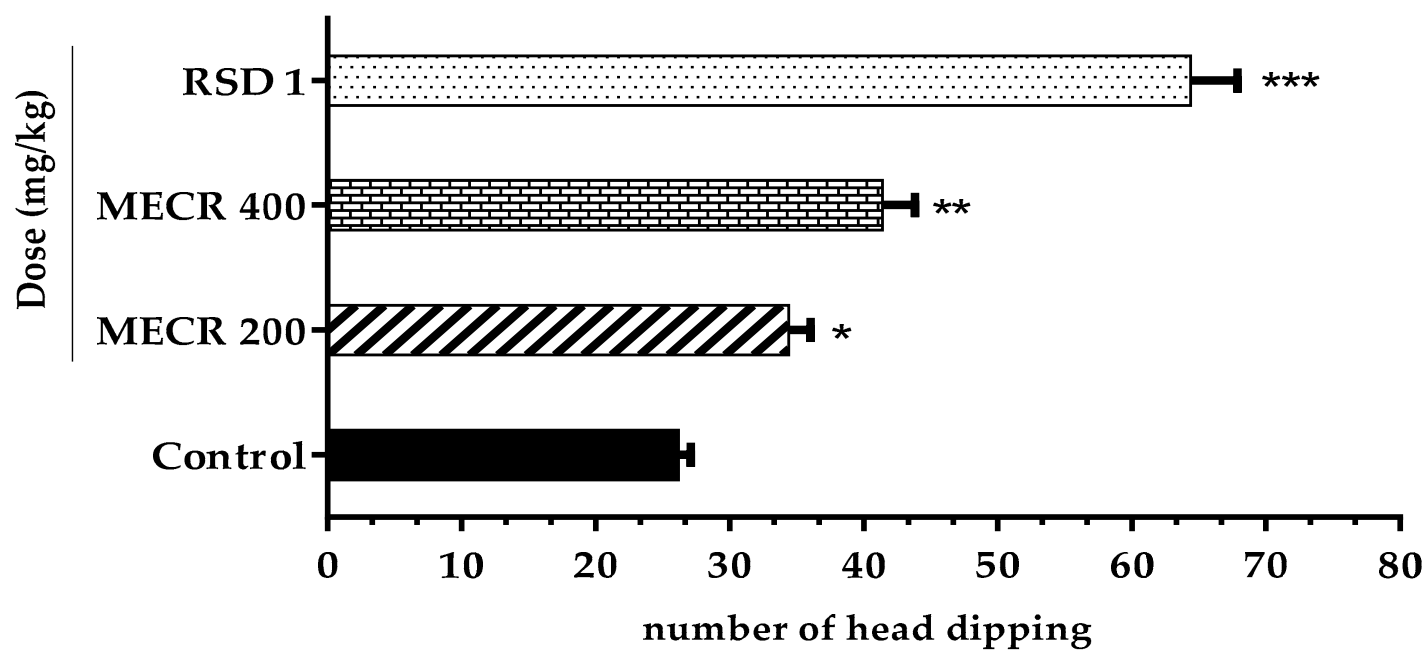

Figure 2. The effect of methanol extract of Cuscuta reflexa (MECR) in hole board test in mice. Values are expressed in mean \pm SEM $(\mathrm{n}=6) .{ }^{*} p<0.05,{ }^{* *} p<0.01$ and ${ }^{* * *} p<0.001$ compared to control (Dunnett's test). RSD: reference standard drug (Diazepam, $1 \mathrm{mg} / \mathrm{kg}$ ).

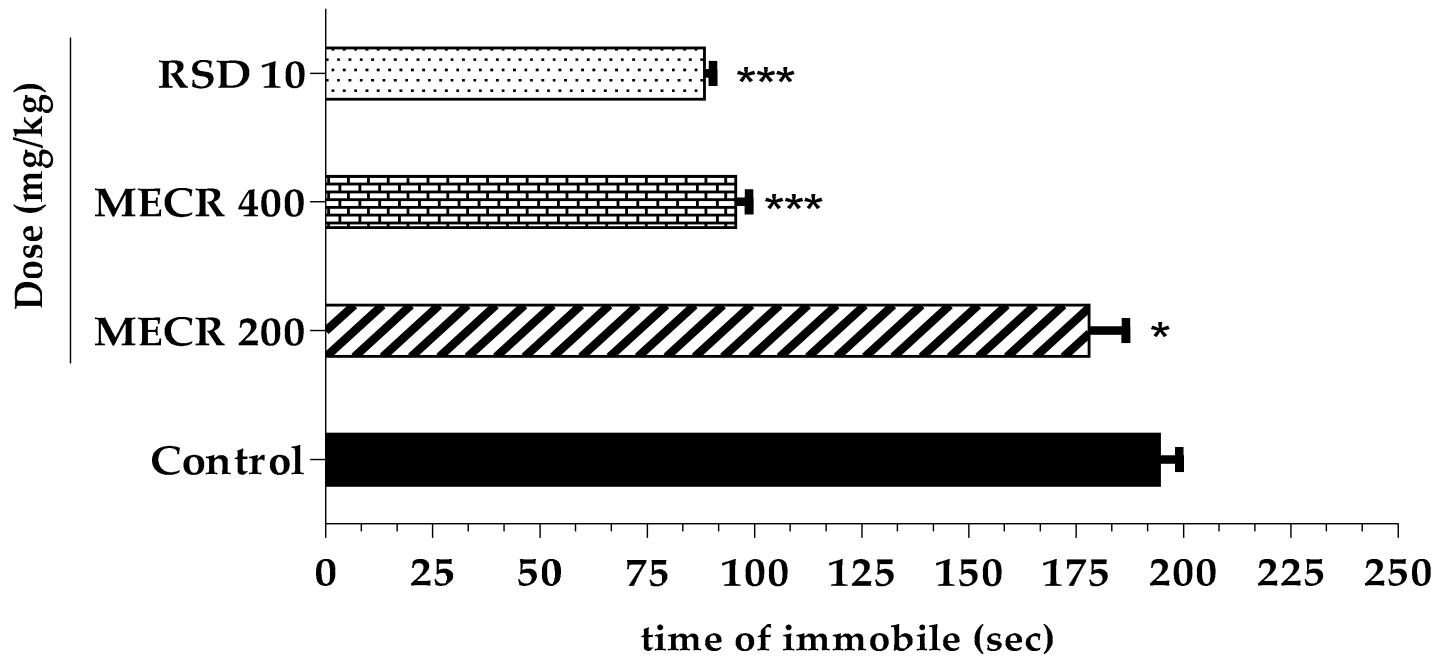

Figure 3. The effects of methanol extract of Cuscuta reflexa (MECR) in forced swimming test in mice. Values are expressed in mean \pm SEM $(n=6)$. ${ }^{*} p<0.05$ and ${ }^{* * *} p<0.001$ compared to control (Dunnett's test). RSD: reference standard drug (Imipramine hydrochloride, $10 \mathrm{mg} / \mathrm{kg}$ ).

Tail Suspension Test (TST)

Outcome of tail suspension test is shown in Figure 4. In this test, treatment of MECR at both (200 and $400 \mathrm{mg} / \mathrm{kg}$ ) doses exhibited antidepressant like action. Both doses demonstrated significant reduction of immobility time by $11.02 \%(p<0.05)$ and $27.31 \%(p<0.001)$, respectively. The decreased immobile time was recorded $182.4 \pm 8.70 \mathrm{~s}$ for $200 \mathrm{mg} / \mathrm{kg}$ and $149 \pm 6.25 \mathrm{~s}$ for $400 \mathrm{mg} / \mathrm{kg}$ in comparison to control $205 \pm 0.70 \mathrm{~s}$. However, standard drug imipramine $(10 \mathrm{mg} / \mathrm{kg})$ revealed a significant $(p<0.001)$ decrease of immobile time $(82.2 \pm 0.86 \mathrm{~s})$ with a $59.90 \%$ antidepressant effect.

\subsection{Acetic Acid-Induced Writhing Test}

Figure 5 represents the inhibitory potential of MECR against acetic acid induced abdominal (writhing) pain in mice. The writhing extent was remarkably suppressed by the outstanding anti-nociceptive response of MECR at both doses ( 400 and $200 \mathrm{mg} / \mathrm{kg}$ ). Writhing numbers and percentage of writhing inhibition for the doses of 200 and $400 \mathrm{mg} / \mathrm{kg}$ were counted $27 \pm 0.70(54.23 \%)$ and $19.2 \pm 0.37$ 
$(67.45 \%)$ respectively, compared to the control $(59 \pm 0.70)$ group. The most effective writhing inhibition was noted $77.62 \%$ with mean writhing number $13.2 \pm 0.86(p<0.001)$ for the reference standard drug "diclofenac sodium" (10 mg/kg).

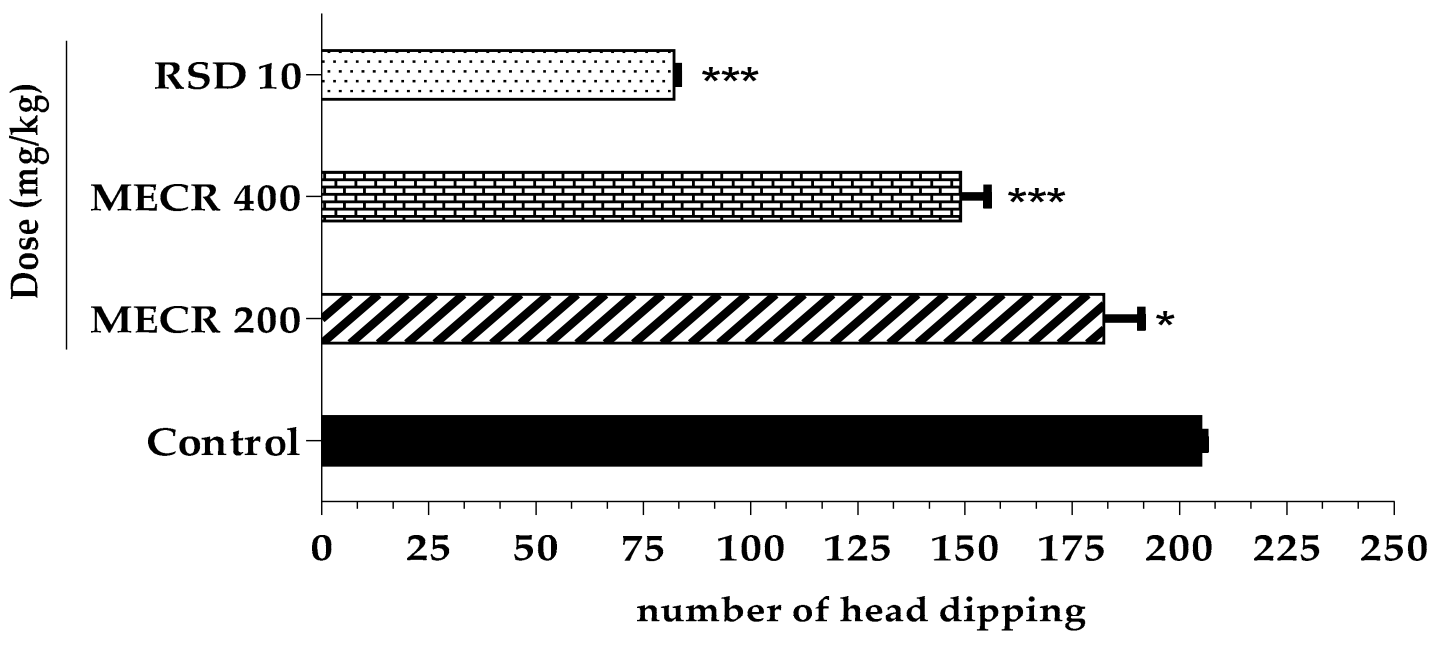

Figure 4. The effect of methanol extract of Cuscuta reflexa (MECR) in tail suspension test in mice. Values are expressed in mean $\pm \operatorname{SEM}(\mathrm{n}=6) .{ }^{*} p<0.05$ and ${ }^{* * *} p<0.001$ compared to control (Dunnett's test). RSD: reference standard drug (Imipramine hydrochloride, $10 \mathrm{mg} / \mathrm{kg}$ ).

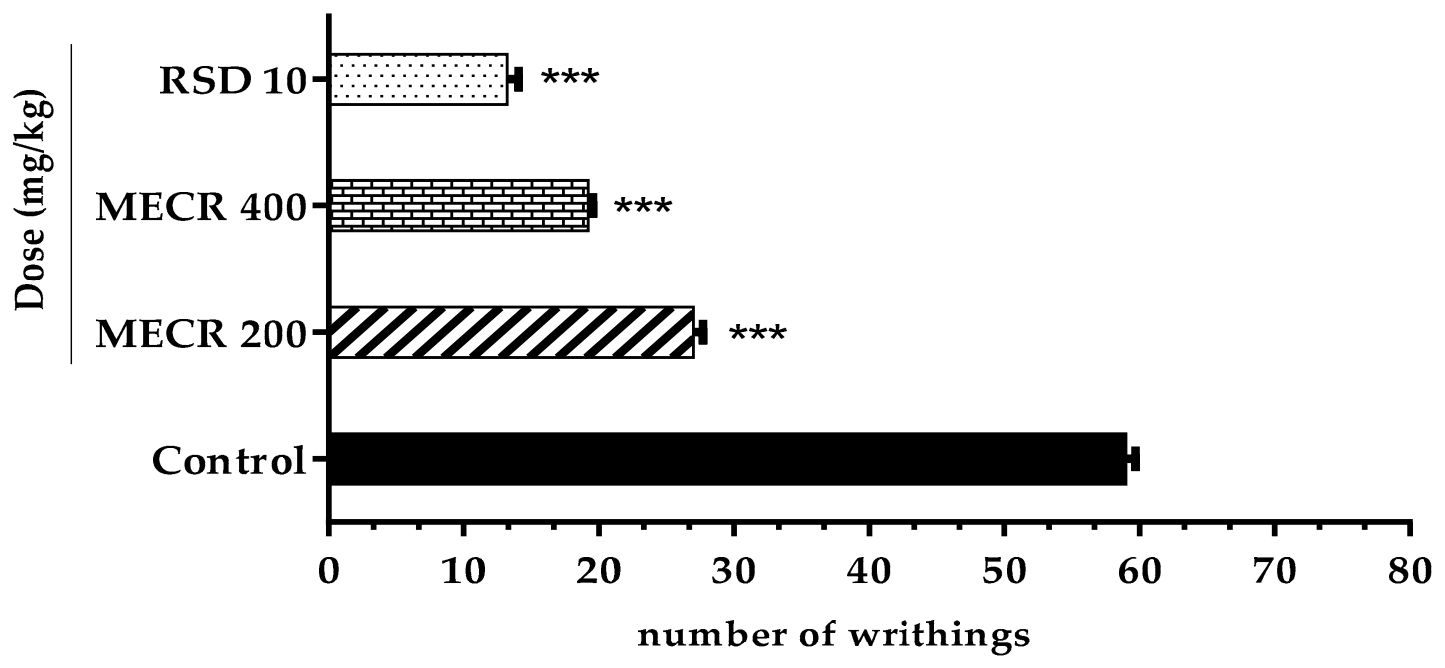

Figure 5. The effect of methanol extract of Cuscuta reflexa (MECR) in acetic acid-induced writhing test in mice. Values are expressed in mean $\pm \operatorname{SEM}(n=6) .{ }^{* * *} p<0.001$ compared to control (Dunnett's test). RSD: reference standard drug (Diclofenac sodium, $10 \mathrm{mg} / \mathrm{kg}$ ).

Formalin Induced Licking Test

Both doses (200 and $400 \mathrm{mg} / \mathrm{kg}$ ) of MECR significantly $(p<0.001)$ attenuated formalin induced neurogenic ( $5 \mathrm{~min}$ ) and inflammatory (15-30 $\mathrm{min}$ ) phases of the pain response in mice (Table 1). During the early (neurogenic pain) phase, paw licking duration for $400 \mathrm{mg} / \mathrm{kg}$ was recorded as $31.00 \pm 0.70 \mathrm{~s}$, with pain inhibition of $45.61 \%$, while late (inflammatory pain) exposed $50.00 \%$ pain inhibition with licking duration of $20.80 \pm 1.77 \mathrm{~s}$. Similarly, dose of $200 \mathrm{mg} / \mathrm{kg}$ alleviated both neurogenic and inflammatory pain by $33.33 \%$ and $37.50 \%$, respectively. The standard drug (diclofenac sodium $10 \mathrm{mg} / \mathrm{kg}$ ) also produced obvious pain inhibition by $73.85 \%$ in the early phase and $67.30 \%$ in the late phase. 
Table 1. Anti-nociceptive effect of MECR in formalin induced paw licking test in mice.

\begin{tabular}{ccccc}
\hline & \multicolumn{4}{c}{ Licking Time (s) (Mean \pm SEM) } \\
\cline { 2 - 5 } Treatment (mg/kg) & $\begin{array}{c}\text { Early Phase } \\
\mathbf{( 0 - 5} \mathbf{~ m i n )}\end{array}$ & Inhibition (\%) & $\begin{array}{c}\text { Late Phase } \\
\mathbf{( 1 5 - 3 0 ~} \mathbf{~ m i n )}\end{array}$ & Inhibition (\%) \\
\hline Control & $57.00 \pm 1.14$ & - & $41.60 \pm 1.02$ & - \\
RSD 10 & $14.90 \pm 0.71^{* * *}$ & 73.85 & $13.60 \pm 0.92^{* * *}$ & 67.30 \\
MECR 200 & $38.00 \pm 2.02$ & 33.33 & $26.00 \pm 1.09^{* * *}$ & 37.50 \\
MECR 400 & $31.00 \pm 0.70^{* * *}$ & 45.61 & $20.80 \pm 1.77^{* * *}$ & 50.00
\end{tabular}

Each value is expressed as mean \pm SEM $(n=6) .{ }^{* * *} P<0.001$ compared with the control group (Dunnett's test). MECR, methanol extract of Cuscuta reflexa leaves; RSD: reference standard drug (Diclofenac $\mathrm{Na}, 10 \mathrm{mg} / \mathrm{kg}$ ).

\subsection{Castor Oil-Induced Diarrhea}

The outcomes following various doses of MECR (200 and $400 \mathrm{mg} / \mathrm{kg}$ ) on castor oil-induced diarrhea are summarized in Table 2. A dose dependent inhibition of diarrhea was observed, while $400 \mathrm{mg} / \mathrm{kg}$ demonstrated maximum inhibition $(55.12 \%, p<0.001)$, which was higher than the anti-diarrheal activity of standard drug loperamide $53.84 \%(p<0.001)$. The number of defecation was also significantly $(p<0.001)$ reduced for $400 \mathrm{~kg} / \mathrm{mg}(7.00 \pm 0.44)$, with an inhibition of $51.38 \%$ defecation compared to the control, whereas loperamide showed $73.61 \%$ inhibition of defecation.

Table 2. The effect of MECR on feces count in castor oil-induced diarrhea in mice.

\begin{tabular}{ccccc}
\hline $\begin{array}{c}\text { Treatment } \\
(\mathbf{m g} / \mathbf{k g})\end{array}$ & $\begin{array}{c}\text { Total Number } \\
\text { of Dry Feces }\end{array}$ & $\begin{array}{c}\text { \% of Inhibition } \\
\text { of Defecation }\end{array}$ & $\begin{array}{c}\text { Total Number of } \\
\text { Diarrheal Feces }\end{array}$ & $\begin{array}{c}\text { \% of Inhibition } \\
\text { of Diarrhea }\end{array}$ \\
\hline Control & $14.40 \pm 0.74$ & - & $15.60 \pm 0.74$ & - \\
RSD 5 & $3.80 \pm 1.01^{* * *}$ & 73.61 & $7.20 \pm 0.37^{* * *}$ & 53.84 \\
MECR 200 & $9.60 \pm 0.67^{* *}$ & 33.33 & $13.20 \pm 1.15$ & 15.38 \\
MECR 400 & $7.00 \pm 0.44^{* * *}$ & 51.38 & $7.00 \pm 0.83^{* * *}$ & 55.12 \\
\hline
\end{tabular}

Each value is expressed as mean $\pm \operatorname{SEM}(\mathrm{n}=6){ }^{* * *} P<0.01$ and ${ }^{* * *} P<0.001$ compared with the control group (Dunnett's test). MECR, methanol extract of Cuscuta reflexa leaves; RSD: reference standard drug (Loperamide, $5 \mathrm{mg} / \mathrm{kg})$.

\subsection{Molecular Docking Study for Anxiolytic and Antidepressant Activity}

In the case of the anxiolytic docking study, fifteen selected compounds from Cuscuta reflexa were docked against the potassium channel (PDB: 4UUJ) receptor and displayed the docking scores ranging from +0.71 to $-6.42 \mathrm{kcal} / \mathrm{mol}$. The results of the docking study are shown in Table 3, and the docking figures are presented in Supplementary Figures S1 and S2. From the results, it was observed that the compounds Myricetin $(-6.42 \mathrm{kcal} / \mathrm{mol})$ exposed the highest score against target receptor, followed by quercetin $(-5.75 \mathrm{kcal} / \mathrm{mol})$, isorhamnetol $(-5.56 \mathrm{kcal} / \mathrm{mol})$, kaempferol $(-5.55 \mathrm{kcal} / \mathrm{mol})$, luteolin $(-5.35 \mathrm{kcal} / \mathrm{mol})$, astragalin $(-4.94 \mathrm{kcal} / \mathrm{mol})$, coumarin $(-4.56 \mathrm{kcal} / \mathrm{mol})$, sesamin $(-3.88 \mathrm{kcal} / \mathrm{mol})$, $\beta$-sitosterol $(-3.63 \mathrm{kcal} / \mathrm{mol}), \alpha$-amyrin $(-2.70 \mathrm{kcal} / \mathrm{mol}), n$-hentriacontane $(-2.18 \mathrm{kcal} / \mathrm{mol})$, and linoleic acid $(+0.71 \mathrm{kcal} / \mathrm{mol})$. The reference standard drug, diazepam, showed the docking score -3.73 $\mathrm{kcal} / \mathrm{mol}$ against potassium channel (PDB: $4 \mathrm{UUJ}$ ) receptor. Conversely, for antidepressant docking analysis, our study demonstrated that astragalin and palmitic acid have the highest and lowest binding affinity against the human serotonin receptor (PDB: 5I6X) with a docking score of $-9.23 \mathrm{kcal} / \mathrm{mol}$ and $+0.94 \mathrm{kcal} / \mathrm{mol}$ respectively. The ranking order of docking score for antidepressant effect is as follow: astragalin $>$ myricetin $>$ isorhamnetol $>$ sesamin $>$ quercetin $>$ kaempferol $>$ luteolin $>$ coumarin $>$ linoleic acid $>$ oleic acid $>$ stearic acid $>$ palmitic acid. The reference standard drug, imipramine hydrochloride exposed the docking score $-8.11 \mathrm{kcal} / \mathrm{mol}$ against the human serotonin receptor (PDB: 5I6X). 
Table 3. Docking score of the selected isolated compounds of Cuscuta reflexa.

\begin{tabular}{cccccccc}
\hline \multirow{2}{*}{ Compounds } & PubChem ID & \multicolumn{7}{c}{ Docking Score } \\
\cline { 3 - 8 } & & 2OYE & 6COX & 4UUJ & 5I6X & 4U14 & 5AIN \\
\hline Kaempferol & 5280863 & -8.61 & -6.70 & -5.55 & -6.94 & -7.90 & -5.53 \\
Astragalin & 5282102 & -6.15 & - & -4.94 & $-\mathbf{9 . 2 3}$ & $-\mathbf{9 . 8 8}$ & - \\
Myricetin & 5281672 & -7.03 & -4.94 & -6.42 & -7.60 & -7.68 & -5.18 \\
Quercetin & 5280343 & -8.52 & -7.11 & -5.75 & -7.13 & -7.78 & -6.13 \\
Isorhamnetol & 5281654 & -7.75 & -8.27 & -5.56 & -7.56 & -7.81 & -5.39 \\
Linoleic acid & 5280934 & -2.12 & -0.76 & 0.71 & -2.44 & -3.63 & -1.19 \\
Oleic acid & 445639 & -2.84 & -1.88 & - & -2.39 & -3.39 & -0.96 \\
Stearic acid & 5281 & -2.02 & -2.69 & - & -1.49 & -2.00 & -0.63 \\
Palmitic acid & 985 & -1.66 & 0.18 & - & -0.94 & -1.88 & 0.66 \\
$\beta$-sitosterol & 22284 & - & - & -3.63 & -6.97 & - & - \\
Luteolin & 5280445 & -8.35 & -8.58 & -5.35 & -6.94 & -8.44 & -5.11 \\
Coumarin & 323 & -7.91 & -7.01 & -4.56 & -6.84 & -7.09 & -5.94 \\
$n$-Hentriacontane & 12410 & - & - & -2.18 & - & - & - \\
$\alpha$-amyrin & 73170 & - & - & -2.70 & -6.34 & - & - \\
Sesamin & 72307 & -8.52 & -6.43 & -3.88 & -7.15 & -6.93 & -3.90 \\
Standard drug: & & & & & & \\
Diclofenac-Na/Diazepam/ & -7.31 & -7.71 & -3.73 & -8.11 & -7.39 & - \\
Imipramine/Loperamide & & & & & & \\
\hline
\end{tabular}

\subsubsection{Molecular Docking Study for Anti-Nociceptive Activity}

The results of anti-nociceptive docking study are presented in Table 3, and the docking figures are displayed in Supplementary Figures S3 and S4. The present study exhibited that kaempferol and palmitic acid have the upmost and lowest binding affinity against the COX-1 enzyme (PDB: 2OYE) with a docking score of $-8.61 \mathrm{kcal} / \mathrm{mol}$ and $-1.66 \mathrm{kcal} / \mathrm{mol}$ respectively. The ranking order of docking score is given below: kaempferol $>$ quercetin $>$ sesamin $>$ luteolin $>$ coumarin $>$ isorhamnetol $>$ myricetin $>$ astragalin $>$ oleic acid $>$ linoleic acid $>$ stearic acid $>$ palmitic acid. On the other hand, luteolin and palmitic acid demonstrated the highest and lowest binding affinity against the COX-2 enzyme (PDB: $6 C O X$ ) with a docking score of $-8.58 \mathrm{kcal} / \mathrm{mol}$ and $+0.18 \mathrm{kcal} / \mathrm{mol}$ respectively. The ranking order of docking score is as follow: luteolin $>$ isorhamnetol $>$ quercetin $>$ coumarin $>$ kaempferol $>$ sesamin $>$ myricetin $>$ stearic acid $>$ oleic acid $>$ linoleic acid $>$ palmitic acid. The reference standard drug, diclofenac-Na, manifested the binding affinity against COX-1 and COX-2 enzymes are $-7.31 \mathrm{kcal} / \mathrm{mol}$ and $-7.71 \mathrm{kcal} / \mathrm{mol}$, respectively.

\subsubsection{Molecular Docking Study for Antidiarrheal Activity}

In this case, astragalin and palmitic acid have demonstrated the maximum and lowermost binding affinity against M3 muscarinic acetylcholine receptor (PDB ID: 4U14) with a docking score of -9.88 $\mathrm{kcal} / \mathrm{mol}$ and $-1.88 \mathrm{kcal} / \mathrm{mol}$ respectively. The ranking order of docking score is presented below: astragalin $>$ luteolin $>$ kaempferol $>$ isorhamnetol $>$ quercetin $>$ myricetin $>$ coumarin $>$ sesamin $>$ linoleic acid $>$ oleic acid $>$ stearic acid $>$ palmitic acid. Loperamide (reference drug) exposed -7.39 $\mathrm{kcal} / \mathrm{mol}$ binding affinity against M3 muscarinic acetylcholine receptor (PDB ID: 4U14). In contrast, quercetin and stearic acid displayed the highest and lowest binding affinity against 5-HT3 receptor (PDB ID: 5AIN) with the docking score of $-6.13 \mathrm{kcal} / \mathrm{mol}$ and $-0.63 \mathrm{kcal} / \mathrm{mol}$, respectively. The ranking order of docking score is presented: quercetin $>$ coumarin $>$ kaempferol $>$ isorhamnetol $>$ myricetin $>$ luteolin $>$ sesamin $>$ linoleic acid $>$ oleic acid $>$ palmitic acid $>$ stearic acid. The results of the docking study are shown in Table 3, and the docking figures are presented in Supplementary Figures S5 and S6. However, based on the highest docking score against all investigated receptors, five major compounds were documented (Figure 6) and their binding interactions are presented in Table 4. 
<smiles>O=c1c(O)c(-c2cc(O)c(O)c(O)c2)oc2cc(O)cc(O)c12</smiles>

Myricetin<smiles>O=c1c(O)c(-c2ccc(O)c(O)c2)oc2cc(O)cc(O)c12</smiles>

Quercetin<smiles>O=c1c(O)c(-c2ccc(O)cc2)oc2cc(O)cc(O)c12</smiles>

Kaempferol<smiles>O=c1cc(-c2ccc(O)c(O)c2)oc2cc(O)cc(O)c12</smiles>

Luteolin<smiles>O=c1c(O[C@@H]2O[C@H](CO)[C@@H](O)[C@H](O)[C@H]2O)c(-c2ccc(O)cc2)oc2cc(O)cc(O)c12</smiles>

Astragalin

Figure 6. Chemical structures of major bioactive compounds identified in the MECR.

\subsection{Pharmacokinetic (ADME) and Toxicological Properties Prediction}

Per Lipinski's rules of five, the pharmacokinetic properties of the selected compounds were calculated using an online tool, SwissADME. Here, Lipinski stated that a drug/compound would be orally bioavailable if it follows the following criteria such as molecular weight $<500 \mathrm{amu}$, Hydrogen bond acceptor sites $<10$, Hydrogen bond donor sites $<5$, and Lipophilicity value $\log P \leq 5$. Result of the present study exhibited that all the compounds, except "astragalin", satisfied Lipinski's rules, which indicates that these compounds have good oral bioavailability (Table 5). 
Table 4. Binding interactions of the major five compounds identified in the molecular docking study.

\begin{tabular}{|c|c|c|c|c|c|}
\hline \multirow{2}{*}{ Proteins } & \multirow{2}{*}{ Ligands } & \multicolumn{2}{|c|}{ Hydrogen Bond Interactions } & \multicolumn{2}{|c|}{ Hydrophobic Interactions } \\
\hline & & Amino Acid Residue & Distance (£) & Amino Acid Residue & Distance ( \\
\hline 2OYE & Kaempferol & SER-530 & 3.93 & $\begin{array}{c}\text { ILE-523 } \\
\text { VAL-349 } \\
\text { ALA-527 } \\
\text { LEU-352 } \\
\text { GLY-526 } \\
\text { TYR-385 }\end{array}$ & $\begin{array}{l}5.41 \\
6.15 \\
4.83 \\
5.11 \\
4.45 \\
6.79 \\
2.43\end{array}$ \\
\hline $6 \mathrm{COX}$ & Luteolin & $\begin{array}{c}\text { SER-530 } \\
\text { ARG-120 } \\
\text { LEU-352 } \\
\text { GLN-192 }\end{array}$ & $\begin{array}{l}3.14 \\
5.80 \\
3.83 \\
5.82\end{array}$ & $\begin{array}{l}\text { VAL-349 } \\
\text { ALA-527 } \\
\text { VAL-523 } \\
\text { SER-353 }\end{array}$ & $\begin{array}{l}4.61 \\
5.40 \\
5.21 \\
4.03 \\
4.68 \\
4.11 \\
4.03\end{array}$ \\
\hline $4 \mathrm{UUJ}$ & Myricetin & $\begin{array}{l}\text { GLU-62 } \\
\text { GLY-53 } \\
\text { ARG-57 } \\
\text { LEU-86 }\end{array}$ & $\begin{array}{l}5.53 \\
4.15 \\
4.88 \\
7.62 \\
4.80\end{array}$ & $\begin{array}{l}\text { PRO-55 } \\
\text { ALA-54 }\end{array}$ & $\begin{array}{l}4.97 \\
5.07 \\
4.79\end{array}$ \\
\hline $5 \mathrm{I} 6 \mathrm{X}$ & Astragalin & $\begin{array}{c}\text { THR-497 } \\
\text { TYR-175 } \\
\text { ASP-98 }\end{array}$ & $\begin{array}{l}3.94 \\
3.45 \\
5.77 \\
4.69\end{array}$ & $\begin{array}{l}\text { TYR-176 } \\
\text { TYR-95 }\end{array}$ & $\begin{array}{l}7.30 \\
5.18 \\
6.40\end{array}$ \\
\hline $4 \mathrm{U} 14$ & Astragalin & $\begin{array}{l}\text { CYS-532 } \\
\text { TYR-529 } \\
\text { TYR-148 } \\
\text { THR-231 } \\
\text { ASN-507 } \\
\text { ASN-152 }\end{array}$ & $\begin{array}{l}4.15 \\
3.10 \\
4.85 \\
4.45 \\
3.82 \\
3.36\end{array}$ & $\begin{array}{l}\text { TYR-529 } \\
\text { ALA-523 } \\
\text { CYS-532 } \\
\text { TRP-503 }\end{array}$ & $\begin{array}{l}7.30 \\
6.80 \\
6.08 \\
4.67 \\
6.03 \\
5.55 \\
\end{array}$ \\
\hline $5 \mathrm{AIN}$ & Quercetin & $\begin{array}{l}\text { GLU-191 } \\
\text { TRP-145 }\end{array}$ & $\begin{array}{l}3.76 \\
4.55\end{array}$ & $\begin{array}{l}\text { TYR193 } \\
\text { TYR186 } \\
\text { TRP-145 }\end{array}$ & $\begin{array}{l}6.84 \\
7.22 \\
6.68 \\
4.81\end{array}$ \\
\hline
\end{tabular}

Table 5. Physicochemical properties of the compounds for good oral bioavailability.

\begin{tabular}{|c|c|c|c|c|c|}
\hline \multirow{3}{*}{ Compounds } & \multicolumn{4}{|c|}{ Lipinski Rules } & \multirow{2}{*}{ Lipinski's Violations } \\
\hline & MW & HBA & HBD & $\log P$ & \\
\hline & $<500$ & $<10$ & $\leq 5$ & $\leq 5$ & $\leq 1$ \\
\hline Kaempferol & 286.24 & 6 & 4 & 1.58 & 0 \\
\hline Astragalin & 448.38 & 11 & 7 & -0.25 & 2 \\
\hline Myricetin & 318.24 & 8 & 6 & 0.79 & 1 \\
\hline Quercetin & 302.24 & 7 & 5 & 1.23 & 0 \\
\hline Luteolin & 286.24 & 6 & 4 & 1.73 & 0 \\
\hline
\end{tabular}

MW, Molecular weight (g/mol); HBA, Hydrogen bond acceptor; HBD, Hydrogen bond donor; Log P, Lipophilicity; NRB: number of rotatable bond; TPSA: topological polar surface area.

In addition, toxicological properties of the five selected compounds were also predicted using admetSAR online server, where our study showed that the selected compounds were non-Ames toxic, non-carcinogenic, and demonstrated weak rat acute toxicity properties (Table 6). 
Table 6. Toxicological properties of the major five compounds identified in the molecular docking study.

\begin{tabular}{cccccc}
\hline \multirow{2}{*}{ Parameters } & \multicolumn{5}{c}{ Compound Name } \\
\cline { 2 - 6 } & Kaempferol & Luteolin & Myricetin & Astragalin & Quercetin \\
\hline Ames toxicity & NAT & NAT & NAT & AT & NAT \\
Carcinogens & NC & NC & NC & NC & NC \\
Acute oral toxicity & II & II & II & III & II \\
Rat acute toxicity & 3.0825 & 3.0200 & 3.0200 & 2.3869 & 3.0200 \\
\hline
\end{tabular}

AT: Ames toxic; NAT: Non Ames toxic; NC: Non-carcinogenic; Category-II means ( $50 \mathrm{mg} / \mathrm{kg}>\mathrm{LD}_{50}<500 \mathrm{mg} / \mathrm{kg}$ ); Category-III means $\left(500 \mathrm{mg} / \mathrm{kg}>\mathrm{LD}_{50}<5000 \mathrm{mg} / \mathrm{kg}\right)$.

\section{Discussion}

Neurological disarrays such as anxiety and depression are the most common emotional disorders and represent an ever-cumulative intimidation to public health [35]. It is suggested by different corroborations that depressive and anxiety disorders correspond to and do not generate individually distinct disease entities [36]. Although the particular etiology of anxiety and depression remains in a great mystery, one of the most possible stimulators of these syndromes is chronic pain, which has an extreme reciprocal correlation with anxiety and depression [37]. Interestingly, the clinical expressions, neurotransmitters, pro-inflammatory cytokines, and neurological pathways of pain and depression have parallel manifestation [38]. Moreover, the mechanisms of neurotransmitters such as serotonin and norepinephrine, have an analogous role for modulating depression and pain signaling pathways in the brain and nervous system [39]. Hence, patients with such chronic pain may suffer from anxiety, accompanied by a progressive depressive state.

Currently, selective serotonin and/or serotonin-norepinephrine reuptake inhibitors along with voltage-dependent calcium channels $\alpha 2 \delta$ subunit ligands are considered as top-line synthetic antidepressant drugs of choice for treating chronic pain [40]. Likewise, standard pharmaceutical agents, some potential herbs such as California poppy, Saint John's Wort, Passionflower, Kava, and Saffron have been suggested for the management of anxiety, depression, and neurological based chronic pain [41]. However, to develop classical lead compounds from a medicinal plant having manifold pharmacological actions, the implementation of innovative animal prototypes and well-validated tests are inevitable to get a reliable preclinical and clinical conclusion [42]. Hence, we have designed in vivo preclinical investigations whether Cuscuta reflexa leaves or its isolated components have the multifaceted pharmacological possessions in mitigating the neuropsychiatric disorders and neurobiological based protracted pain. Therefore, we have assessed anxiolytic, antidepressant, anti-nociceptive, and antidiarrheal potentials of methanol extract of Cuscuta reflexa leaves, utilizing suitable animal research models which accurately reflect various aspects of human psychopathology.

To verify the anxiolytic activity of MECR, we utilized elevated plus maze (EPM) and hole board (HB) animal models $[43,44]$. Both tests are regarded as popular paradigms due to the quick valuation of the possible anxiety modulating responses in mice. The typical EPM tool has two opposite open and two bounded arms, whereas the open arena is supposed to be more fearful for the animals, and an anxiolytic agent stimulates the mice to open arm exploration [45]. Similarly, the hole board test (HBT) has been designed to measure the exploratory responses and multiple dimensions of the unconditioned behavior of a mouse to an unfamiliar environment [46]. The manifestation of more hole poking (head dipping) tendency indicates a high level of anxiolytic activity, while the hesitancy expression of visiting the hole results from a high level of anxiety. However, during the experiment, mice treated with MECR (200 and $400 \mathrm{mg} / \mathrm{kg}$ ) demonstrated a reduction in anxiety-like behavior by reflecting increased entries to, and time spent in the open alleys as well as elevated the exploratory behavior followed by demonstrating the higher number of head dipping. The neurobiological mechanism of anxiety is the result of either an imbalance of neurotransmitter (dopamine, GABA, and serotonin) function or dysregulation of glutamatergic, serotonergic, GABA-ergic, and noradrenergic transmission [47]. In our experiment, MECR may exert anxiolytic actions by modifying neurotransmitter synthesis 
and functions. It is supposed that active components of MECR interact with the neurotransmitter or neuromodulator receptors, which regulate the neuronal communication, stimulate the CNS activity, and improve the function of endocrine systems [48].

Some potential anxiolytic herbs, such as $R$. rosea and $C$. sativus have been proven to have antidepressant activity [49]. This bilateral neuropharmacological action has been known as "halo effect," of which once anxiety is cured efficiently, depression may also be de-escalated [50]. Generally, the dysfunction of the corticotrophin-releasing factor (CRF) due to over activation of the hypothalamic-pituitary-adrenal (HPA) axis causes the manifestation of depressive symptoms [51]. Nevertheless, effective antidepressant treatment suppresses the stress-induced HPA axis activation, followed by restoring the rational expression and function of CRF [52]. In our study, MECR was further subjected to a force swimming test (FST) and tail suspension test (TST) to explore antidepressant-like activity as well as the pathological mechanism of depression. The ambient of FST and TST are very stressful, where without using antidepressant agent, mice reflect a state of behavioral despair e.g., immobility (passive behavior). However, MECR (200 and $400 \mathrm{mg} / \mathrm{kg}$ ) treatment in mice revealed dynamic behaviors, such as decreased immobility in swimming test and increased struggling tendency in tail suspension test. These noteworthy antidepressant-like effects of MECR might be either due to the inhibition of monoamine reuptake or significant suppression of HPA axis activation.

Numerous studies on animal models have reported that antidepressant treatments (tricyclic antidepressants and serotonin noradrenaline reuptake inhibitors) are beneficial to reduce protracted pain, such as neuropathic pain [38]. It was found that the accumulation of noradrenaline in the spinal cord by reuptake inhibition can efficiently suppress neuropathic pain through $\alpha 2$ adrenergic receptors. Although the precise mechanisms of antidepressants underlying treatment of persistent pain remain uncertain, currently available preclinical and clinical outcomes revealed that several neurotransmitters, neuromodulators, mainly, serotonin-norepinephrine reuptake inhibitors may be the most viable mediators for the modulation of prolonged pain like neuropathic pain symptoms [53]. Meanwhile, the anxiolytic and antidepressant activity of MECR has been found in a promising level; and importantly, C. reflexa is used for the treatment of low back pain in traditional medicine. Therefore, we intended to explore the anti-nociceptive action of MECR further.

To evaluate peripherally reactive analgesics, we investigated acetic acid stimulated writhing test in mice. Induction of acetic acid causes immediate liberation of endogenous pain mediators; also, various visceral pro-inflammatory mediators or chemo-sensitive nociceptors are activated and released, which further enter into the dorsal horn of the central nervous system by aggravating peripheral neurons [26]. This mechanism of acetic acid is responsible for abdominal constriction (visceral pain) and pain sensation followed by the manifestation of writhing in mice [54]. However, during our experiment, MECR (200 and $400 \mathrm{mg} / \mathrm{kg}$ ) dose-dependently inhibited abdominal constriction in mice, resulting in notable anti-nociceptive activity, which perhaps due to the presence of potential analgesic components in MECR inhibiting the release of pain mediators.

Although the anti-nociceptive effects of MECR in the writhing test does not delineate whether central or peripheral processes mediate the responses. Hence, we conducted a formalin induce leaking test in order to clarify neurogenic and inflammatory pain responses [26]. Formalin (intra-planter injection) triggers incessant nociception characterized by a biphasic pain reaction [55]. The initial phase $(0-5 \mathrm{~min})$ is associated with the acute nociceptive neurogenic pain, possibly due to provocation of sensory $\mathrm{C}$ and $\mathrm{A} \delta$ fibers through neuropeptide, for instance, substance P. The late phase (15-30 min) relates to inflammatory nociception which stimulates to release various chemical mediators, such as histamine, serotonin, amino acids, prostaglandins, and bradykinin. Importantly, drugs that have the central effect can inhibit the mediators of both phases, while peripherally acting drugs suppress only the mediators of the late phase [54,56]. In this regard, MECR suppressed both phases of mediators, confirmed by the substantial anti-nociceptive activity in a dose-dependent fashion, which indicates that MECR possesses the potential phytoconstituents with central effects. 
During the antidiarrheal test, the administrated castor oil $(0.5 \mathrm{~mL}$, natural laxative) releases its active metabolite "ricinoleic acid" through the action of small intestinal lipase [57]. The liberated ricinoleic acid then binds with EP3 prostanoid receptors on smooth muscle cells, which suppress electrolytes and water absorption from the intestine, causing dysfunction and noxious effect in the intestine [58]. In addition, ricinoleic acid induces local inflammation in the intestine through stimulation of various pro-inflammatory mediators, such as prostaglandin biosynthesis, which also responsible for the inhibition of water and ions reabsorption [59]. Any antidiarrheal agent like loperamide accelerates the absorption rate, followed by reducing movement and volume of intestinal contents [27]. Analagous to this mechanism, MECR at all doses showed a dose-dependent antidiarrheal action, demonstrated by a significant inhibitory response, in terms of both defecation rate and diarrhea.

During comprehensive analyses, MECR at $400 \mathrm{mg} / \mathrm{kg}$ was found to be most effective in all experiments which might be due to the combined action of important phytoconstituents, in addition to those isolated and potentially other as yet uncharacterized bioactive compounds possess in MECR. However, for the practical implementation of this dose to the human purpose, it is necessary to identify and isolate the pure components responsible for the observed biological effects. In addition, in acute toxicity test, all measured doses (10 to $1500 \mathrm{mg} / \mathrm{kg}$ ) did not expose any noticeable indication of toxicity, behavioral abnormalities, and potential defects on motor activities (excitability and sedation). Moreover, overt toxicological effects, particularly physical changes (allergic reaction and loss of body weight), were not observed, which confirmed that MECR has no toxic effects up to $1500 \mathrm{mg} / \mathrm{kg}$.

Molecular docking is a vital tool in structural molecular biology and computer-assisted drug design (CADD). This tool contributes to predicting the binding mode of active compounds against the essential proteins [60]. Additionally, it is used to comprehend the possible molecular mechanism of actions of various pharmacological activities [27]. However, to correlate with the findings of our current experimental results, molecular docking was performed to understand the molecular mechanism better. In this study, fifteen major compounds of Cuscuta reflexa were examined against six target receptors or enzymes, namely, potassium channel receptor (PDB: 4UUJ), human serotonin receptor (PDB: 5I6X), cyclooxygenase-1 (COX-1, PDB: 2OYE) and cyclooxygenase-2 enzymes (COX-2, PDB: 3HS5), M3 muscarinic acetylcholine receptor (PDB ID: 4U14), and 5-HT3 receptor (PDB ID: $5 \mathrm{AIN}$ ). Among the fifteen, eleven phytocompounds (kaempferol, astragalin, myricetin, quercetin, isorhamnetol, linoleic acid, $\beta$-sitosterol, luteolin, coumarin, $\alpha$-amyrin, and sesamin) were found which docked against both the potassium channel receptor (PDB: 4UUJ) and human serotonin receptor (PDB: 5I6X) for anxiolytic and antidepressant activity respectively. The anxiolytic and antidepressant activity of the MECR might thus be explained by the presence of kaempferol [61], quercetin [62], isorhamnetol [63], linoleic acid [64], coumarin [65], $\alpha$-amyrin [66], and sesamin [67], which manifested excellent docking scores and for which bioactivities have previously been reported.

The same eleven phyto-compounds were also detected in common, which docked against both COX-1 and COX-2 enzymes. It has been previously reported that kaempferol [61], myricetin, quercetin [62], isorhamnetol [63], linoleic acid [64], oleic acid [68], stearic acid [69], palmitic acid [70], luteolin [71], coumarin [65], sesamin [67] possess analgesic and anti-inflammatory properties, which perhaps the possible reason for the anti-nociceptive activity of MECR.

In the antidiarrheal docking analysis, similar (eleven) phyto-compounds also docked against both M3 muscarinic acetylcholine receptor and 5-HT3 receptor, such as kaempferol, myricetin, quercetin, isorhamnetol, linoleic acid, oleic acid, stearic acid, palmitic acid, luteolin, coumarin, sesamin. From these results, we can conclude that the studied phyto-compounds might, in part, be responsible for the antidiarrheal activity of MECR through interaction with these target receptors.

Furthermore, according to the highest score in the molecular docking study, five compounds have been selected, namely kaempferol, luteolin, myricetin, astragalin, and quercetin, to examine their $\mathrm{ADME} / \mathrm{T}$ and toxicological properties further. According to Lipinski's rule of five, orally administered drugs should have a molecular weight $<500 \mathrm{amu}$, Hydrogen bond acceptor sites $<10$, Hydrogen bond donor sites $<5$, and Lipophilicity value, $\log \mathrm{P} \leq 5$. If any drugs/compounds violate all of 
these rules, it will not be considered as good oral bioavailability [72,73]. Our study exhibited that none of the phyto-compounds except "astragalin" violated these rules, which indicate good oral bioavailability of the documented bioactive compounds. The study of toxicology demonstrated that none of the compounds posed a risk of Ames toxicity, carcinogenicity, acute oral toxicity, and weak rat acute toxicity. Therefore, all five phytocompounds could be considered for promising drug candidates with good oral bioavailability.

\section{Conclusion}

Collectively, the experimental pharmacological evidences support the folkloric value and potentiality of this plant. In this study, MECR has been proved to have noteworthy anxiolytic and antidepressant efficacy. The study also demonstrated that MECR possesses remarkable anti-nociceptive activity which was verified by various pain models. In addition, significant and dose dependent response regarding antidiarrheal activity has enhanced the value of this plant. Furthermore, various identified active compounds from Cuscuta reflexa revealed a promising binding attraction towards different proteins in molecular docking analysis. Importantly, the selected active compounds have manifested their drug-like characteristics and safeness in ADME/T and toxicology studies. Overall, Cuscuta reflexa can be considered as a sustainable candidate for the development of new drug having multiple pharmacological effects. However, further investigations are required to identify the pure active compounds and their molecular mechanisms also need to be explored for long term safety.

Supplementary Materials: The following are available online at http://www.mdpi.com/1424-8247/13/3/50/s1, Figure S1. 2D interactions of the Kaempferol (A), Astragalin (B), Myricetin (C), Quercetin (D), Isorhamnetol (E), Linoleic acid (F), B-sitosterol, Luteolin (G), Coumarin (H), n-Hentriacontane (I), $\alpha$-amyrin (J), and Sesamin (K) with the active site of potassium channel (PDB: $4 \mathrm{UUJ})$ receptor for anxiolytic activity. Colors indicate the residue (or species) type: Red-acidic (Asp, Glu), Green-hydrophobic (Ala, Val,Ile, Leu, Tyr, Phe, Trp, Met, Cys, Pro), Purple-basic (Hip, Lys, Arg), Blue-polar (Ser, Thr, Gln, Asn, His, Hie, Hid), Light gray-other (Gly, water) and Darker gray-metal atoms. Interactions with the protein are marked with lines between ligand atoms and protein residues: Solid pink: H-bonds to the protein backbone, Dotted pink: H-bonds to protein side chains, Green: pi-pi stacking interactions, Orange: pi-cation interactions. Ligand atoms exposed to solvent are marked with gray spheres. The protein "pocket" is displayed with a line around the ligand, colored with the color of the nearest protein residue. The gap in the line shows the opening of the pocket. Figure S2. 2D interactions of the Kaempferol (A), Astragalin (B), Myricetin (C), Quercetin (D), Isorhamnetol (E), Linoleic acid (F), Oleic acid (G), Stearic acid (H), Palmitic acid (I), B-sitosterol (J), Luteolin (K), Coumarin (L), $\alpha$-amyrin (M), and Sesamin (N) with the active site of human serotonin receptor (PDB: 5I6X) for antidepressant activity. Figure S3. 2D interactions of the Kaempferol (A), Astragalin (B), Myricetin (C), Quercetin (D), Isorhamnetol (E), Linoleic acid (F), Oleic acid (G), Stearic acid $(\mathrm{H})$, Palmitic acid (I), Luteolin (J), Coumarin (K), and Sesamin (L) with the active site of with COX-1 (PDB: 2OYE) enzyme for anti-nociceptive activity. Figure S4. 2D interactions of the Kaempferol (A), Myricetin (B), Quercetin (C), Isorhamnetol (D), Linoleic acid (E), Oleic acid (F), Stearic acid (G), Palmitic acid (H), Luteolin (I), Coumarin (J), and Sesamin (K) with the active site of with COX-2 (PDB: 6COX) enzyme for anti-nociceptive activity. Figure S5. 2D interactions of the Kaempferol (A), Astragalin (B), Myricetin (C), Quercetin (D), Isorhamnetol (E), Linoleic acid $(\mathrm{F})$, Oleic acid (G), Stearic acid (H), Palmitic acid (I), Luteolin (J), Coumarin (K), and Sesamin (L) with the active site of M3 muscarinic acetylcholine receptor (PDB ID: 4U14) for antidiarrheal activity. Figure S6. 2D interactions of the Kaempferol (A), Myricetin (B), Quercetin (C), Isorhamnetol (D), Linoleic acid (E), Oleic acid (F), Stearic acid $(\mathrm{G})$, Palmitic acid $(\mathrm{H})$, Luteolin $(\mathrm{I})$, Coumarin (J), and Sesamin (K) with the active site of 5-HT3 receptor (PDB ID: 5AIN) for antidiarrheal activity.

Author Contributions: M.A. and M.N.U.C. conceived and designed the experiments, prepared the plant extract, carried out all the experimental works and collected and analyzed the data. M.A. drafted the final manuscript. M.N.U.C. and M.A. performed the in silico studies. M.R.C., M.S.I., M.A.H., A.M.T., M.I.H.B., M.N.U., A.T., and M.O.K.A., revised and improved the manuscript. A.T.M.M.K., and Y.S.L., validated all experimental protocols and co-supervised this study, and D.H.C. supervised this study. All authors have read and agreed to the published version of the manuscript.

Funding: This research did not receive any specific grant from funding agencies in the public, commercial, or not-for-profit sectors.

Acknowledgments: This research was supported by the Department of Pharmacy, International Islamic University Chittagong-4318, Bangladesh and Kangwon National University, Chuncheon, 24341, Republic of Korea.

Conflicts of Interest: The authors declare no conflict of interest. 


\section{Abbreviations}

MECR refers to methanol extract of Cuscuta reflexa leaves

p.o. per oral;

i.p. Intraperitoneal;

ANOVA Analysis of variance;

BW body weight;

SEM standard error of mean;

SPSS statistical package for social science.

ADME/T Absorption, Distribution, Metabolism, Excretion, and Toxicity;

PASS Prediction of Activity Spectra for Substances.

\section{References}

1. Hosseinzadeh, S.; Jafarikukhdan, A.; Hosseini, A.; Armand, R. The application of medicinal plants in traditional and modern medicine: A review of Thymus vulgaris. Int. J. Clin. Med. 2015, 6, 635. [CrossRef]

2. Adnan, M.; Chy, M.N.U.; Rudra, S.; Tahamina, A.; Das, R.; Tanim, M.A.H.; Siddique, T.I.; Hoque, A.; Tasnim, S.M.; Paul, A.; et al. Evaluation of Bonamia semidigyna (Roxb.) for antioxidant, antibacterial, anthelmintic and cytotoxic properties with the involvement of polyphenols. Orient. Pharm. Exp. Med. 2019, 19, 187-199. [CrossRef]

3. Rasool Hassan, B. Medicinal Plants (Importance and Uses). Pharm. Anal. Acta 2012. [CrossRef]

4. Jamshidi-Kia, F.; Lorigooini, Z.; Amini-Khoei, H. Medicinal plants: Past history and future perspective. J. Herbmed Pharmacol. 2018, 7. [CrossRef]

5. Ritchie, H.; Roser, M. Mental Health; Our World in Data: Oxford, UK, 2018.

6. Sewell, R.D.E.; Rafieian-Kopaei, M. The history and ups and downs of herbal medicines usage. J. Herbmed Pharmacol. 2014, 3, 1-3.

7. Slater, D.; Kunnathil, S.; McBride, J.; Koppala, R. Pharmacology of nonsteroidal antiinflammatory drugs and opioids. In Seminars in Interventional Radiology; Thieme Medical Publishers: New York, NY, USA, 2010; Volume 27, pp. 400-411.

8. Antman, E.M.; Bennett, J.S.; Daugherty, A.; Furberg, C.; Roberts, H.; Taubert, K.A. Use of nonsteroidal antiinflammatory drugs: An update for clinicians: A scientific statement from the American Heart Association. Circulation 2007, 115, 1634-1642. [CrossRef] [PubMed]

9. Almeida, R.N.; Navarro, D.S.; Barbosa-Filho, J.M. Plants with central analgesic activity. Phytomedicine 2001, 8, 310-322. [CrossRef]

10. Swati, R.K.; Richa, K. A review on antidiarrhoeal activity of herbals. Int. J. Res. Pharm. Biomed. Sci. 2011, 2, 1357-1362.

11. Snyder, J.D.; Merson, M.H. The magnitude of the global problem of acute diarrhoeal disease: A review of active surveillance data. Bull. World Health Organ. 1982, 60, 605.

12. Wichtl, M. Herbal Drugs and Phytopharmaceuticals: A Handbook for Practice on a Scientific Basis; Medpharm GmbH Scientific Publishers: Stuttgart, Germany, 2004; ISBN 3887631005.

13. Patel, S.; Sharma, V.; Chauhan, N.S.; Dixit, V.K. An updated review on the parasitic herb of Cuscuta reflexa Roxb. J. Chin. Integr. Med. 2012, 10, 249-255. [CrossRef]

14. Pandit, S.; Chauhan, N.S.; Dixit, V.K. Effect of Cuscuta reflexa Roxb on androgen-induced alopecia. J. Cosmet. Dermatol. 2008, 7, 199-204. [CrossRef] [PubMed]

15. Hossan, M.S.; Hanif, A.; Khan, M.; Bari, S.; Jahan, R.; Rahmatullah, M. Ethnobotanical survey of the Tripura tribe of Bangladesh. Am. Eurasian J. Sustain. Agric. 2009, 3, 253-261.

16. Siwakoti, M.; Siwakoti, S. Ethnomedicinal uses of plants among the Satar tribe of Nepal. J. Econ. Taxon. Bot. 2000, 24, 323-333.

17. Gupta, M.; Mazumder, U.K.; Pal, D.K.; Bhattacharya, S. Anti-steroidogenic activity of methanolic extract of Cuscuta reflexa Roxb. stem and Corchorus olitorius Linn. seed in mouse ovary. Indian J. Exp. Biol. 2003, 41, 641-644. [PubMed]

18. Vijikumar, S. Cuscuta reflexa Roxb—A wonderful miracle plant in ethnomedicine. Indian J. Nat. Sci. Int. Bimon. 2011, 976, 997. 
19. Rahmatullah, M.; Sultan, S.; Toma, T.; Lucky, S.; Chowdhury, M.; Haque, W.; Annay, E.; Jahan, R. Effect of Cuscuta reflexa stem and Calotropis procera leaf extracts on glucose tolerance in glucose-induced hyperglycemic rats and mice. Afr. J. Tradit. Complement. Altern. Med. 2010, 7, 109-112. [CrossRef]

20. Pal, D.K.; Mandal, M.; Senthilkumar, G.P.; Padhiari, A. Antibacterial activity of Cuscuta reflexa stem and Corchorus olitorius seed. Fitoterapia 2006, 77, 589-591. [CrossRef]

21. Anis, E.; Anis, I.; Ahmed, S.; Mustafa, G.; Malik, A.; Afza, N.; Hai, S.M.A.; Choudhary, M.I. $\alpha$-glucosidase inhibitory constituents from Cuscuta reflexa. Chem. Pharm. Bull. 2002, 50, 112-114. [CrossRef]

22. Pellow, S.; File, S.E. Anxiolytic and anxiogenic drug effects on exploratory activity in an elevated plus-maze: A novel test of anxiety in the rat. Pharmacol. Biochem. Behav. 1986, 24, 525-529. [CrossRef]

23. Sonavane, G.S.; Sarveiya, V.P.; Kasture, V.S.; Kasture, S.B. Anxiogenic activity of Myristica fragrans seeds. Pharmacol. Biochem. Behav. 2002, 71, 239-244. [CrossRef]

24. Porsolt, R.D.; Bertin, A.; Jalfre, M. Behavioral despair in mice: A primary screening test for antidepressants. Arch. Int. Pharmacodyn. Thérapie 1977, 229, 327-336.

25. Steru, L.; Chermat, R.; Thierry, B.; Simon, P. The tail suspension test: A new method for screening antidepressants in mice. Psychopharmacology 1985, 85, 367-370. [CrossRef] [PubMed]

26. Adnan, M.; Nazim Uddin Chy, M.; Mostafa Kamal, A.T.M.; Barlow, J.W.; Faruque, M.O.; Yang, X.; Uddin, S.B. Evaluation of anti-nociceptive and anti-inflammatory activities of the methanol extract of Holigarna caustica (Dennst.) Oken leaves. J. Ethnopharmacol. 2019, 236. [CrossRef] [PubMed]

27. Adnan, M.; Chy, N.U.; Mostafa Kamal, A.T.M.; Azad, M.O.K.; Paul, A.; Uddin, S.B.; Barlow, J.W.; Faruque, M.O.; Park, C.H.; Cho, D.H. Investigation of the Biological Activities and Characterization of Bioactive Constituents of Ophiorrhiza rugosa var. prostrata (D. Don) \& Mondal Leaves through In Vivo, In Vitro, and In Silico Approaches. Molecules 2019, 24, 1367. [CrossRef]

28. Berman, H.M.; Battistuz, T.; Bhat, T.N.; Bluhm, W.F.; Bourne, P.E.; Burkhardt, K.; Feng, Z.; Gilliland, G.L.; Iype, L.; Jain, S. The protein data bank. Acta Crystallogr. D Biol. Crystallogr. 2002, 58, 899-907. [CrossRef]

29. Lenaeus, M.J.; Burdette, D.; Wagner, T.; Focia, P.J.; Gross, A. Structures of KcsA in complex with symmetrical quaternary ammonium compounds reveal a hydrophobic binding site. Biochemistry 2014, 53, 5365-5373. [CrossRef]

30. Coleman, J.A.; Green, E.M.; Gouaux, E. X-ray structures and mechanism of the human serotonin transporter. Nature 2016, 532, 334. [CrossRef]

31. Harman, C.A.; Turman, M.V.; Kozak, K.R.; Marnett, L.J.; Smith, W.L.; Garavito, R.M. Structural basis of enantioselective inhibition of cyclooxygenase- 1 by S- $\alpha$-substituted indomethacin ethanolamides. J. Biol. Chem. 2007, 282, 28096-28105. [CrossRef]

32. Vecchio, A.J.; Simmons, D.M.; Malkowski, M.G. Structural basis of fatty acid substrate binding to cyclooxygenase-2. J. Biol. Chem. 2010, 285, 22152-22163. [CrossRef]

33. Thorsen, T.S.; Matt, R.; Weis, W.I.; Kobilka, B.K. Modified T4 lysozyme fusion proteins facilitate G protein-coupled receptor crystallogenesis. Structure 2014, 22, 1657-1664. [CrossRef]

34. Price, K.L.; Lillestol, R.K.; Ulens, C.; Lummis, S.C.R. Varenicline interactions at the 5-HT3 receptor ligand binding site are revealed by 5-HTBP. ACS Chem. Neurosci. 2015, 6, 1151-1157. [CrossRef] [PubMed]

35. Möller, H.-J.; Bandelow, B.; Volz, H.-P.; Barnikol, U.B.; Seifritz, E.; Kasper, S. The relevance of 'mixed anxiety and depression'as a diagnostic category in clinical practice. Eur. Arch. Psychiatry Clin. Neurosci. 2016, 266, 725-736. [CrossRef] [PubMed]

36. Kara, S.; Yazici, K.M.; Güleç, C.; Ünsal, I. Mixed anxiety-depressive disorder and major depressive disorder: Comparison of the severity of illness and biological variables. Psychiatry Res. 2000, 94, 59-66. [CrossRef]

37. Berton, O.; Nestler, E.J. New approaches to antidepressant drug discovery: Beyond monoamines. Nat. Rev. Neurosci. 2006, 7, 137. [CrossRef] [PubMed]

38. Han, C.; Pae, C.-U. Pain and depression: A neurobiological perspective of their relationship. Psychiatry Investig. 2015, 12, 1. [CrossRef] [PubMed]

39. Marks, D.M.; Shah, M.J.; Patkar, A.A.; Masand, P.S.; Park, G.-Y.; Pae, C.-U. Serotonin-norepinephrine reuptake inhibitors for pain control: Premise and promise. Curr. Neuropharmacol. 2009, 7, 331-336. [CrossRef]

40. Küpeli Akkol, E.; Gürağaç Dereli, F.T.; Ilhan, M. Assessment of Antidepressant Effect of the Aerial Parts of Micromeria myrtifolia Boiss. \& Hohen on Mice. Molecules 2019, 24, 1869. [CrossRef]

41. Penn, E.; Tracy, D.K. The drugs don't work? Antidepressants and the current and future pharmacological management of depression. Ther. Adv. Psychopharmacol. 2012, 2, 179-188. [CrossRef] 
42. Balunas, M.J.; Kinghorn, A.D. Drug discovery from medicinal plants. Life Sci. 2005, 78, 431-441. [CrossRef]

43. Lister, R.G. The use of a plus-maze to measure anxiety in the mouse. Psychopharmacology 1987, 92, 180-185. [CrossRef]

44. Thoeringer, C.K.; Erhardt, A.; Sillaber, I.; Mueller, M.B.; Ohl, F.; Holsboer, F.; Keck, M.E. Long-term anxiolytic and antidepressant-like behavioural effects of tiagabine, a selective GABA transporter-1 (GAT-1) inhibitor, coincide with a decrease in HPA system activity in C57BL/6 mice. J. Psychopharmacol. 2010, 24, 733-743. [CrossRef] [PubMed]

45. Rodgers, R.J.; Cao, B.-J.; Dalvi, A.; Holmes, A. Animal models of anxiety: An ethological perspective. Brazilian J. Med. Biol. Res. 1997, 30, 289-304. [CrossRef] [PubMed]

46. Sillaber, I.; Panhuysen, M.; Henniger, M.S.H.; Ohl, F.; Kühne, C.; Pütz, B.; Pohl, T.; Deussing, J.M.; Paez-Pereda, M.; Holsboer, F. Profiling of behavioral changes and hippocampal gene expression in mice chronically treated with the SSRI paroxetine. Psychopharmacology 2008, 200, 557-572. [CrossRef]

47. Sarris, J.; Teschke, R.; Stough, C.; Scholey, A.; Schweitzer, I. Re-introduction of kava (Piper methysticum) to the EU: Is there a way forward? Planta Med. 2011, 77, 107-110. [CrossRef] [PubMed]

48. Mennini, T.; Caccia, S.; Garattini, S. Mechanism of action of anxiolytic drugs. In Progress in Drug Research/Fortschritte der Arzneimittelforschung/Progrès des Recherches Pharmaceutiques; Springer: Berlin/Heidelberg, Germany, 1987; pp. 315-347.

49. Sarris, J.; Panossian, A.; Schweitzer, I.; Stough, C.; Scholey, A. Herbal medicine for depression, anxiety and insomnia: A review of psychopharmacology and clinical evidence. Eur. Neuropsychopharmacol. 2011, 21, 841-860. [CrossRef] [PubMed]

50. Wang, Z.; Gu, J.; Wang, X.; Xie, K.; Luan, Q.; Wan, N.; Zhang, Q.; Jiang, H.; Liu, D. Antidepressant-like activity of resveratrol treatment in the forced swim test and tail suspension test in mice: The HPA axis, BDNF expression and phosphorylation of ERK. Pharmacol. Biochem. Behav. 2013, 112, 104-110. [CrossRef] [PubMed]

51. Nestler, E.J.; Barrot, M.; DiLeone, R.J.; Eisch, A.J.; Gold, S.J.; Monteggia, L.M. Neurobiology of depression. Neuron 2002, 34, 13-25. [CrossRef]

52. Arborelius, L.; Owens, M.J.; Plotsky, P.M.; Nemeroff, C.B. The role of corticotropin-releasing factor in depression and anxiety disorders. J. Endocrinol. 1999, 160, 1-12. [CrossRef]

53. Sheng, J.; Liu, S.; Wang, Y.; Cui, R.; Zhang, X. The link between depression and chronic pain: Neural mechanisms in the brain. Neural Plast. 2017, 2017. [CrossRef]

54. Chy, M.N.U.; Adnan, M.; Rauniyar, A.K.; Amin, M.M.; Majumder, M.; Islam, M.S.; Afrin, S.; Farhana, K.; Nesa, F.; Sany, M.A. Evaluation of anti-nociceptive and anti-inflammatory activities of Piper sylvaticum (Roxb.) stem by experimental and computational approaches. Orient. Pharm. Exp. Med. 2019, 1-15. [CrossRef]

55. Shoibe, M.; Chy, M.N.U.; Alam, M.; Adnan, M.; Islam, M.Z.; Nihar, S.W.; Rahman, N.; Suez, E. In vitro and in vivo biological activities of Cissus adnata (Roxb.). Biomedicines 2017, 5, 63. [CrossRef] [PubMed]

56. Auniq, R.B.J.; Chy, M.N.U.; Adnan, M.; Roy, A.; Islam, M.A.; Khan, T.N.; Hasan, M.Z.; Ahmed, S.; Khan, M.F.; Islam, N. Assessment of anti-nociceptive and anthelmintic activities of Vitex Peduncularis Wall. leaves and in silico molecular docking, ADME/T, and PASS prediction studies of its isolated compounds. J. Complement. Med. Res. 2019, 10, 170-185. [CrossRef]

57. Mathias, J.R.; Martin, J.L.; Burns, T.W.; Carlson, G.M.; Shields, R.P. Ricinoleic acid effect on the electrical activity of the small intestine in rabbits. J. Clin. Investig. 1978, 61, 640-644. [CrossRef]

58. Tunaru, S.; Althoff, T.F.; Nüsing, R.M.; Diener, M.; Offermanns, S. Castor oil induces laxation and uterus contraction via ricinoleic acid activating prostaglandin EP3 receptors. Proc. Natl. Acad. Sci. USA 2012, 109, 9179-9184. [CrossRef] [PubMed]

59. Racusen, L.C.; Binder, H.J. Ricinoleic acid stimulation of active anion secretion in colonic mucosa of the rat. J. Clin. Investig. 1979, 63, 743-749. [CrossRef] [PubMed]

60. Khan, S.; Nazir, M.; Raiz, N.; Saleem, M.; Zengin, G.; Fazal, G.; Saleem, H.; Mukhtar, M.; Tousif, M.I.; Tareen, R.B. Phytochemical profiling, in vitro biological properties and in silico studies on Caragana ambigua stocks (Fabaceae): A comprehensive approach. Ind. Crops Prod. 2019, 131, 117-124. [CrossRef]

61. Calderon-Montano, J.M.; Burgos-Morón, E.; Pérez-Guerrero, C.; López-Lázaro, M. A review on the dietary flavonoid kaempferol. Mini Rev. Med. Chem. 2011, 11, 298-344. [CrossRef]

62. Maalik, A.; Khan, F.A.; Mumtaz, A.; Mehmood, A.; Azhar, S.; Atif, M.; Karim, S.; Altaf, Y.; Tariq, I. Pharmacological applications of quercetin and its derivatives: A short review. Trop. J. Pharm. Res. 2014, 13, 1561-1566. [CrossRef] 
63. Kandakumar, S.; Manju, D.V. Pharmacological applications of isorhamnetin: A short review. Int. J. Trend Sci. Res. Dev. 2017, 1, 672-678. [CrossRef]

64. Ekor, M. The growing use of herbal medicines: Issues relating to adverse reactions and challenges in monitoring safety. Front. Pharmacol. 2014, 4, 177. [CrossRef]

65. Wu, L.; Wang, X.; Xu, W.; Farzaneh, F.; Xu, R. The structure and pharmacological functions of coumarins and their derivatives. Curr. Med. Chem. 2009, 16, 4236-4260. [CrossRef] [PubMed]

66. Shinde, U.A.; Phadke, A.S.; Nair, A.M.; Mungantiwar, A.A.; Dikshit, V.J.; Saraf, M.N. Membrane stabilizing activity-A possible mechanism of action for the anti-inflammatory activity of Cedrus deodara wood oil. Fitoterapia 1999, 70, 251-257. [CrossRef]

67. Monteiro, É.M.H.; Chibli, L.A.; Yamamoto, C.H.; Pereira, M.C.S.; Vilela, F.M.P.; Rodarte, M.P.; de Oliveira Pinto, M.A.; Da Penha Henriques do Amaral, M.; Silvério, M.S.; de Matos Araújo, A.L.S. Antinociceptive and anti-inflammatory activities of the sesame oil and sesamin. Nutrients 2014, 6, 1931-1944. [CrossRef] [PubMed]

68. Carrillo Pérez, C.; Camarero, C.; del Mar, M.; Alonso de la Torre, S. Role of oleic acid in immune system; mechanism of action; a review. Nutr. Hosp. 2012, 27, 978-990.

69. Shoba, F.G.; Thomas, M. Study of antidiarrhoeal activity of four medicinal plants in castor-oil induced diarrhoea. J. Ethnopharmacol. 2001, 76, 73-76. [CrossRef]

70. Wang, Y.; Qian, Y.; Fang, Q.; Zhong, P.; Li, W.; Wang, L.; Fu, W.; Zhang, Y.; Xu, Z.; Li, X. Saturated palmitic acid induces myocardial inflammatory injuries through direct binding to TLR4 accessory protein MD2. Nat. Commun. 2017, 8, 13997. [CrossRef]

71. Aziz, N.; Kim, M.-Y.; Cho, J.Y. Anti-inflammatory effects of luteolin: A review of in vitro, in vivo, and in silico studies. J. Ethnopharmacol. 2018, 225, 342-358. [CrossRef]

72. Lipinski, C.A.; Lombardo, F.; Dominy, B.W.; Feeney, P.J. Experimental and computational approaches to estimate solubility and permeability in drug discovery and development settings. Adv. Drug Deliv. Rev. 1997, 23, 3-25. [CrossRef]

73. Duffy, F.J.; Devocelle, M.; Shields, D.C. Computational approaches to developing short cyclic peptide modulators of protein-protein interactions. In Computational Peptidology; Springer: Berlin/Heidelberg, Germany, 2015; pp. 241-271.

(C) 2020 by the authors. Licensee MDPI, Basel, Switzerland. This article is an open access article distributed under the terms and conditions of the Creative Commons Attribution (CC BY) license (http://creativecommons.org/licenses/by/4.0/). 